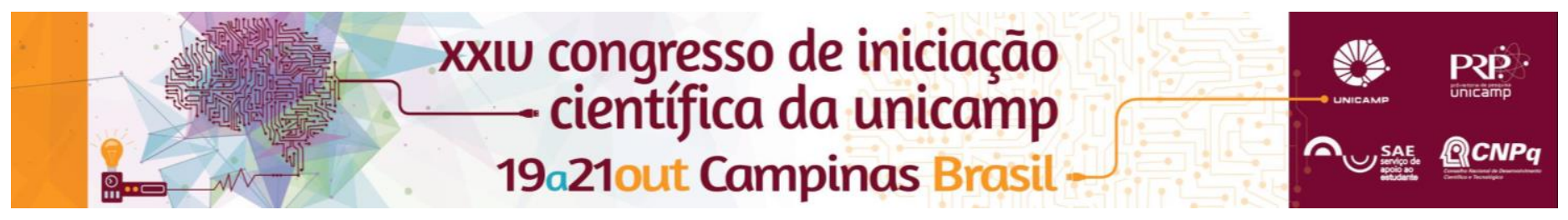

\title{
PREPARAÇÃO E CARACTERIZAÇÃO DE SCAFFOLDS DE ÁCIDO HIALURÔNICO E QUITOSANA PARA APLICAÇÕES EM MEDICINA REGENERATIVA
}

\author{
Lucas M. Pina*, Andréa A. M. Shimojo, Maria Helena A. Santana.
}

\section{Resumo}

O presente projeto tem como objetivo preparar e caracterizar scaffolds porosos de ácido hialurônico autorreticulado (AHA) e de ácido hialurônico autorreticulado conjugado com quitosana (AHA-CHT) para aplicação na cicatrização de feridas envolvendo particularmente a liberação controlada de fatores de crescimento do plasma rico em plaquetas (PRP). AHA foi obtido por reação de autoesterificação organocatalisada e AHA-CHT foi obtido por coacervação complexa. Os scaffolds foram preparados por congelamento à $-20^{\circ} \mathrm{C}$ e liofilização. Foi também realizado um estudo de escalonamento/otimização dos processos.

\section{Palavras-chave:}

Ácido hialurônico, quitosana, scaffolds.

\section{Introdução}

Os polissacarídeos naturais são os materiais mais atraentes para a preparação de scaffolds, principalmente devido às suas semelhanças com a matriz extracelular, versatilidade química, bom desempenho biológico, e interações celulares específicas. O ácido hialurônico $(\mathrm{AH})$ é um polissacarídeo natural linear composto de repetidas unidades dissacarídicas de ácido $\beta$ - $(1 \rightarrow 4)$-Dglicurônico e $\beta$-(1 $\rightarrow 3)$-D-N-acetilglicosamina presente nos tecidos conjuntivos que pode influenciar diversas funções celulares, tais como migração, adesão e proliferação. Embora $\mathrm{o} A \mathrm{H}$, na sua forma livre e reticulada, tenha sido amplamente utilizado como scaffolds, sua elevada densidade de carga negativa pode reduzir principalmente a adesão celular ${ }^{1}$. Neste contexto, quitosana (CHT) foi utilizada para reduzir a carga negativa do $\mathrm{AH}$, favorecendo os processos biológicos envolvidos na regeneração tecidual.

\section{Resultados e Discussão}

Os scaffolds foram caracterizados quanto à morfologia, propriedades mecânicas e compatibilidade celular (Figura 1). Os resultados obtidos mostraram que ambos os scaffolds são promissores para aplicação em engenharia de tecidos, particularmente na cicatrização de feridas.

O estudo do aumento de escala do processo de preparação do AHA e do AHA-CHT foi realizado utilizando critérios de semelhança geométrica, fluidodinâmica e manutenção do nível de agitação² (Tabela 1).

Os resultados de razão de intumescimento e o rendimento de ambas as reações indicaram que a manutenção da semelhança fluidodinâmica é o melhor método para realizar o escalonamento do processo.

Além disso, foi também otimizada a preparação do intermediário AH-TBA reduzindo o tempo de processo em $50 \%$.

Tabela 1. Estudo de escalonamento dos processos.

\begin{tabular}{|c|c|c|c|c|}
\hline Scaffolds & $\begin{array}{c}\text { Parâmetros } \\
\text { avaliados }\end{array}$ & $\begin{array}{c}\text { Não } \\
\text { escalonado }\end{array}$ & $\begin{array}{c}\text { Semelhança } \\
\text { Fluidodinâmica }\end{array}$ & $\begin{array}{c}\text { Manutenção do nível de } \\
\text { agitação }\end{array}$ \\
\hline \multirow{2}{*}{ AHA } & Rendimento (\%) & $84 \pm 10$ & $73 \pm 5$ & $82 \pm 5$ \\
\cline { 2 - 5 } & $\mathrm{Rl}$ & $30 \pm 3$ & $48 \pm 7$ & $25 \pm 6$ \\
\hline \multirow{2}{*}{ AHA-CHT } & Rendimento (\%) & $87 \pm 7$ & $84 \pm 4$ & $99 \pm 4$ \\
\cline { 2 - 5 } & $\mathrm{Rl}$ & $36 \pm 3$ & $30 \pm 1$ & 32 \\
\hline
\end{tabular}

${ }^{*} \mathrm{RI}=$ Razão de intumescimento = massa intumescida $(\mathrm{g}) /$ massa seca $(\mathrm{g})$
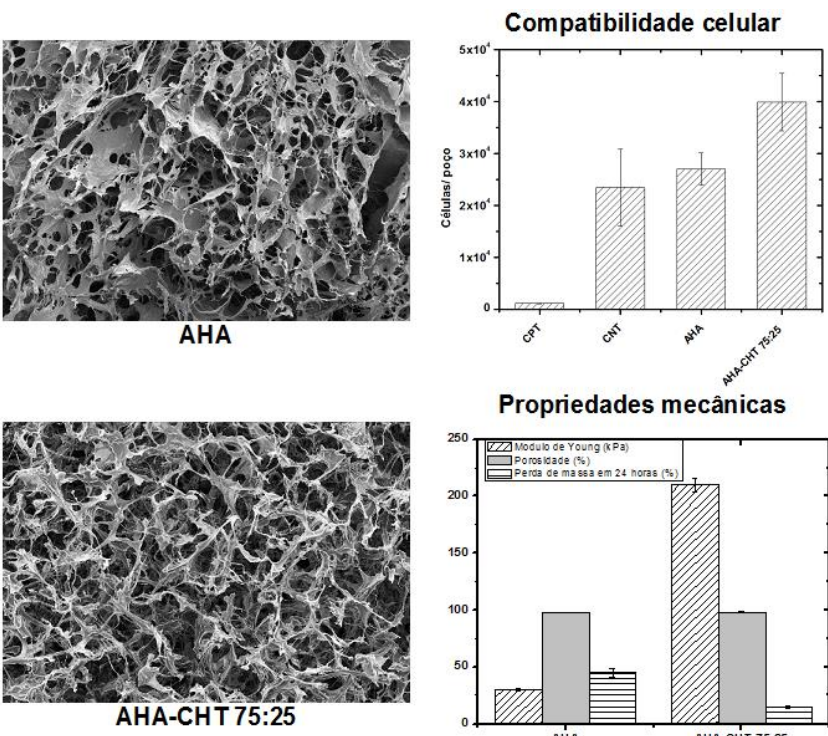

Propriedades mecânicas

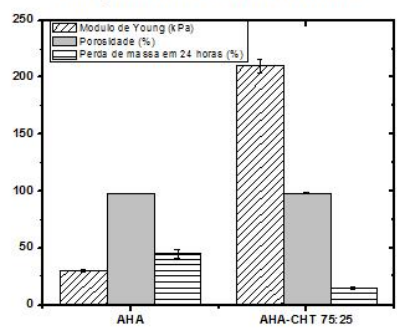

Figura 1. Propriedades mecânicas, morfológicas e compatibilidade celular dos scaffolds de AHA e AHA-CHT 75:25.

\section{Conclusões}

Scaffolds de AHA e AHA-CHT, foram preparados com rendimentos mássicos de $84 \pm 10 \%$ e $73 \pm 3 \%$, respectivamente. Ambos apresentaram compatibilidade celular com h-AdMSCs e propriedades mecânicas e morfológicas adequadas para serem utilizados como scaffolds. O estudo de escalonamento/otimização do processo apresentou melhores resultados mantendo a semelhança fluidodinâmica.

\section{Agradecimentos}

Os autores agradecem o suporte financeiro do Serviço de Apoio ao Estudante (SAE) e ao Centro de Hematologia e Hemoterapia da Unicamp pelo fornecimento das células mesenquimais.

${ }^{1}$ Correia, C. R.; Teixeira, L. S. M.; Moroni, L.; Reis, R. L.; Van Blitterswijk, C. A.; Karperien, M.; Mano, J. F. Tissue Engineering - Part C 2011, 17(7), 717.

${ }^{2}$ Cremasco, M.A. Operações Unitárias em Sistemas Particulados e Fluidomecânicos. São Paulo: Blucher, p.97, 2014. 